\title{
CURRENT ISSUES IN
}

TOURISM

\section{An integrative model of destination brand equity and tourist satisfaction}

\begin{tabular}{|r|l|}
\hline Journal: & Current Issues in Tourism \\
\hline Manuscript ID & CIT-3326.R4 \\
\hline Keywords: & Brand equity, awareness, image, quality, satisfaction, loyalty \\
\hline Abstract: & $\begin{array}{l}\text { This paper develops an integrative model that includes the dimensions of } \\
\text { destination brand equity (i.e. awareness, image, quality and loyalty), as } \\
\text { well as a key behavioral variable that is tourist satisfaction. In particular, } \\
\text { our paper aims to contribute to the literature: 1) by examining the } \\
\text { relationships between the dimensions of destination brand equity, which is } \\
\text { not a deeply investigated issue so far; and 2) by adding tourist } \\
\text { satisfaction, a key concept in loyalty formation, to the variables usually } \\
\text { considered in destination brand equity models. The model was tested in } \\
\text { two samples, national and international tourists visiting a destination in } \\
\text { Spain, in order to also explore the role of the geographical and cultural } \\
\text { distance between tourist and destination. Our results from a multi-group } \\
\text { analysis indicate: 1) a robust link between 'quality-satisfaction-loyalty' in } \\
\text { both samples of tourists; } 2 \text { ) a chain of effects among awareness, image } \\
\text { (separately considering the cognitive and affective dimensions) and } \\
\text { perceived quality, although with the presence of some significant difference } \\
\text { between both samples of tourists; and 3) a positive influence of cognitive } \\
\text { image on affective image in both cases. }\end{array}$ \\
\hline
\end{tabular}




\title{
An integrative model of destination brand equity and tourist satisfaction
}

\begin{abstract}
This paper develops an integrative model that includes the dimensions of destination brand equity (i.e. awareness, image, quality and loyalty), as well as a key behavioral variable that is tourist satisfaction. In particular, our paper aims to contribute to the literature: 1) by examining the relationships between the dimensions of destination brand equity, which is not a deeply investigated issue so far; and 2) by adding tourist satisfaction, a key concept in loyalty formation, to the variables usually considered in destination brand equity models. The model was tested in two samples, national and international tourists visiting a destination in Spain, in order to also explore the role of the geographical and cultural distance between tourist and destination. Our results from a multi-group analysis indicate: 1) a robust link between 'quality-satisfactionloyalty' in both samples of tourists; 2) a chain of effects among awareness, image (separately considering the cognitive and affective dimensions) and perceived quality, although with the presence of some significant difference between both samples of tourists; and 3) a positive influence of cognitive image on affective image in both cases.
\end{abstract}

Key words: Brand equity, awareness, image, quality, satisfaction, loyalty. 


\section{Introduction}

Tourist destinations can be considered products (Boo et al., 2009) which, in a global environment, compete to attract tourists by enhancing their differentiators and competitive advantages (Pike, 2009). With this in mind, one key strategy for achieving positive returns is to develop destination brand. In particular, destination branding is considered a powerful marketing tool to build a positive image of the place and develop emotional links with their visitors (Barnes et al., 2014). Although branding emerged in the marketing literature in the fifties (Gardner \& Levy, 1955) and has an extensive background (Aaker \& Joachimsthaler, 2000), this topic has only attracted the attention of researchers in the field of tourist destinations in recent years (Boo et al., 2009;

Kladou et al., 2015; Pike, 2007, 2010; Yang et al., 2015; Pike \& Bianchi, 2016). Consequently, we still have a long way to go to understand the implications of brand equity in the tourism field.

Nowadays, there is an agreement that the general principles of branding regarding goods and services can be applied in a similar way in the field of tourist destinations (Caldwell \& Freire, 2004; Dioko \& So, 2012). This strategy leads to "brand equity", a concept that can be defined as the overall value created by a brand (Bailey \& Ball, 2006). Taking into account its potential, this paper takes as a starting point the dimensions proposed for customer-based brand equity (i.e. awareness, image, quality perceived and loyalty) and examines the relationships among them in the context of a tourist destination. In this sense, it is important to highlight that, although the dimensions of destination brand equity are examined in more or less extent in some previous studies, the link between each other remains unexplored up to now (Kladou et al., 2015). 
Furthermore, our model contains two more contributions to the academic literature in this field. First, destination image is analyzed by taking into account their two dimensions, the affective and cognitive (Baloglu \& McCleary, 1999; Walmsley \& Young, 1998). While the majority of models published up to now consider only one dimension of image, mainly related to social image and self-image (Bigné et al., 2013; Boo et al., 2009; Pike et al., 2010; Pike \& Bianchi, 2013), or the image as a second order construct composed of several dimensions (Gartner \& Konecnik, 2010), this paper adopts a different approach in order to better understand the role of destination image in destination brand equity. Specifically, we establish that a destination evokes cognitions and emotions among tourists and, consequently, it is necessary to examine the effects of these two dimensions of image (i.e. cognitive image and affective image) separately, as well as the possible link between them.

Second, the model is completed with the inclusion of tourist satisfaction as a direct antecedent of loyalty toward the destination. As established by Van Raaij, Van Veldhoven and Wärneryd (2013), satisfaction is a behavioral phenomenon that is extremely important since it represents the main objective of marketing activities and, in general, a keystone for the well-being of people. Under these circumstances, extensive research on the relationship between consumer satisfaction and loyalty has been previously conducted in the marketing literature and, particularly, in tourism research. However, this causal relationship, which is important to offer an integral view of the study of brand equity, has been only included in destination brand equity models very recently (Ghafari et al. 2017; Bigné et al., 2013; Fuch et al., 2012).

It should be highlighted that our model was empirically tested by carrying out a quantitative research focused on tourists visiting a Spanish destination. Particularly, the 
model was evaluated in two different samples: national tourists and international tourists. Since the different geographical and cultural origins of tourists may lead to different perceptions and mental structures regarding the destination concerned, a multigroup analysis was conducted in order to identify if the chain of effects included in our model of destination brand equity is significantly different or not between the two groups of tourists.

In brief, the overall objective of our paper is to generate new knowledge about destination brand equity by adopting a new approach, which is focused on: 1) the interrelationships among brand equity dimensions, 2) the tourist satisfaction as a key behavioral variable in loyalty formation, and 3) the geographical and cultural distance between tourist and destination as a potential variable influencing the chain of effects in the model. With this in mind, the present paper is organized as follows; first, we provide an overview of the theoretical basis of the paper, justifying our hypotheses and theoretical model. Second, we explain the methodology of this empirical research. Third, we present the findings of the causal model and the possible differences among the groups of tourists. Finally, we summarize the most relevant theoretical and managerial implications, as well as the limitations and future lines of research.

\section{Literature review}

\subsection{Brand equity for a tourist destination}

"Place branding" is becoming a growing area in the field of destination and tourism marketing (Kaplan et al., 2010). Much work has been done in the area of analyzing the image of destinations (Baloglu \& McCleary, 1999; Kladou et al. 2015; Pike \& Ryan, 2004; San Martín \& Rodríguez, 2008), but place branding is a complex and extensive 
field of research, and it is accepted that it cannot be limited to image studies only (Barnes et al., 2014; Kaplan et al., 2010). In general terms, efforts to measure the value of a brand are becoming increasingly important with the need of firms to compete globally (Hsu et al., 2012; Keller, 2003). This value has been conceptualized as brand equity, a multidimensional construct initially proposed by Keller (1993) and Aaker (1996) in the field of goods and services and now extended to places (Bigné et al., 2013; Im et al., 2012; Konecnik, 2006; Konecnik \& Gartner, 2007; Pike et al., 2010; Yang et al., 2015).

Although there are a variety of conceptual approaches, customer-based brand equity can be defined as a measure of the strength of consumers' attachment to a brand or a description of the associations and beliefs the consumer has about the brand (Feldwick, 1996). In this context, destination image is a key variable in the study of brand equity, but other dimensions are also necessary to truly measure this construct (Boo et al., 2009; Konecnik \& Gartner, 2007).

It is accepted that customer-based brand equity encompasses four dimensions: brand awareness, brand image, brand quality and loyalty (Barnes et al., 2014). In this paper, we add a new variable, satisfaction, already included in recent work about destination brand equity (Bigné et al., 2013; Fuchs et al., 2012). In line with previous studies, brand awareness would reflect the tourist's knowledge of a particular destination or the presence of a destination in the minds of tourists when a given travel context is considered (Pike \& Bianchi, 2013). Brand image, often interchangeably referred to as brand associations, would represent the set of associations attached to the destination, composed of a variety of individual perceptions relating to various attributes of the destination that may or may not reflect objective reality (Aaker, 1996). In this sense, it 
is important to differentiate the cognitive image and the affective image. The first one refers to the individual's own knowledge and beliefs about the destination while the affective image is associated with emotions and feelings about it (Baloglu \& McCleary, 1999; Walmsley \& Young, 1998). Brand quality is a holistic judgment made based on the excellence or overall superiority (Bigné et al., 2005). Satisfaction is a tourist's cognitive-affective state derived from his/her experience at the destination (Rodríguez \& San Martín, 2008). Finally, loyalty represents the core dimension of brand equity (Keller, 2003). In tourism, loyalty is usually considered as the intention to revisit the destination and word-of-mouth intentions (Chen \& Myagmarsuren, 2010; Pike, 2007; Prayag, 2012).

\subsection{Chain of effects among the dimensions of brand equity: awareness, image and quality}

First, we analyze the awareness-image relationship. According to different approaches, awareness is a first and necessary step to loyalty (Konecnik, 2006). On the one hand, it is accepted that the higher the level of awareness the more dominant is the brand. This will increase the likelihood that the brand will be a member of the consideration set and will receive serious consideration for purchase (Keller, 1993; Yasin et al., 2007). On the other hand, and according to the associative network model, memory consists of nodes or units of information, defined as stored information connected by links that vary in strength (Anderson, 1993; Keller, 1993). A destination brand represents a potential node, to which a variety of associations is linked, forming a knowledge structure (Pike et al., 2010; Pike \& Bianchi, 2013). According to Keller (2003), once a brand is identified, the customer tends to proffer a meaning to the brand, 
giving rise to brand associations. Brand awareness influences the formation of these associations, so it is to be expected that a greater awareness of a destination will enhance the perception of its brand image (Bigné et al., 2013; Pike et al., 2010; Liu \& Fang, 2016; Ghafari et al. 2017).

In tourism research, destination image (i.e. brand image) is defined as the set of impressions, beliefs, ideas, expectations and feelings accumulated towards a tourist destination over time (Kim \& Richardson, 2003). This approach to destination image, which includes both cognitive and affective associations, has been supported by recent studies about destination image (e.g. Han \& Hwang, 2016; Lim \& Weaver, 2014; Lin et al., 2016; Papadimitriou et al., 2016; Smith et al., 2015; Yacout \& Hefny, 2015). In this sense, since a tourist destination is capable of evoking different emotions, such as pleasure or excitement, among visitors (Walmsley \& Young, 1998), destination image would be represented not only by the beliefs or knowledge an individual has of the attributes of the destination (Pike and Ryan, 2004) but also by his/her feelings toward the place (Chen \& Uysal, 2002; Kim \& Richardson, 2003).

Accordingly, this study adopts a cognitive-affective approach of destination image when establishing the interrelationships between this construct and other variables such as awareness and perceived quality. Therefore, based on the brand equity theory, this research establishes that a greater awareness of the destination will enhance not only the cognitive associations linked to the place by tourists, but also the affective ones.

Consequently, the following hypotheses are established:

H1. Destination awareness will have a direct and positive influence on the cognitive image of the destination. 
H2. Destination awareness will have a direct and positive influence on the affective image of the destination.

Second, previous research on consumer behavior has widely recognized that perceptions of quality are influenced by the perceived image of a product or service (Bloemer et al., 1998). In tourism, the relationship between image and perceived quality, which can be defined as tourists' evaluation of a destination's offerings (Zabkar et al., 2010), has been confirmed in several previous works (Bigné et al., 2001; Bigné et al., 2005; Chen \& Tsai, 2007; Hankinson, 2005; Kim et al., 2013). The image that tourists form of a destination influences the way they perceive the destination's quality. In particular, given that destination image is formed based on a tourist's feelings (affective associations) and perceptions (cognitive associations) concerning a destination's resources and attractions, an improved image will reinforce the quality of the destination as perceived by visitors. With this in mind, the third and fourth hypotheses are established:

H3. The cognitive image of the destination will have a direct and positive influence on its perceived quality.

H4. The affective image of the destination will have a direct and positive influence on its perceived quality.

Finally, and as previously established in the introduction, it is necessary to examine not only the influence of these two dimensions of destination image on other constructs, but also the possible link between them. According to the traditional attitude models 
(Bagozzi, 1982; Fishbein \& Azjen, 1975), the affective evaluations of an attitude object are influenced by the cognitive evaluations of that object, so both dimensions of attitude are closely related. In a similar way, Russell (1980) establishes that information is initially interpreted by individuals and endowed with meaning, and that it subsequently contributes to forming their emotional states. Based on these theoretical arguments, several studies in tourism research have postulated, and empirically confirmed, that the cognitive image of a tourist destination positively influences its affective image (Baloglu \& McCleary, 1999; Beerli \& Martín, 2004; Han \& Hwang, 2016; Lin et al., 2016; Papadimitriou et al., 2016). Consequently, we aim to enhance our model of destination brand equity by including the following hypothesis:

H5. The cognitive image of the destination will have a direct and positive influence on its affective image.

\subsection{The role of tourist satisfaction in loyalty formation}

Customer-based brand equity implies a direct relationship between perceived quality and consumer loyalty. However, according to consumer behavior literature (Gounaris et al., 2010; Srivastava \& Sharma, 2013), if individuals have direct experience with a product (e.g. destination), their future behavior will also be affected by their satisfaction with the consumption experience. Thus, we include this variable in our theoretical model, and we examine the role of satisfaction considering its antecedents and its influence on loyalty towards the destination.

Since previous research on consumer behavior usually establishes that perceived quality is an antecedent of satisfaction (e.g. Cronin et al., 2000; Gounaris et al., 2010; 
Olsen, 2002; Srivastava \& Sharma, 2013), our study postulates a positive relationship between perceived quality and tourist satisfaction. Therefore, satisfaction, which can be defined as a tourist's cognitive-affective state derived from his/her experience at a destination (Rodríguez \& San Martín, 2008), is considered a behavioral variable that plays a key role in the formation of loyalty toward the destination. The relationship quality-satisfaction can be based on the theoretical arguments proposed by Lazarus (1991) and Oliver (1997). According to these authors, consumers develop a behavioral sequence initiated by a cognitive phase (a component that acquires a greater importance in quality judgments) and followed by an emotional phase (a component that shows a greater relevance in satisfaction states). In tourism research, several studies show empirical evidence of a positive relationship between quality and satisfaction (Baker \& Crompton, 2000; Bigné et al., 2001; Chen \& Chen, 2010; Lee et al., 2011; Jin et al., 2015; Petrick, 2004;). Thus, the fifth hypothesis is established:

H6. Destination quality will have a direct and positive influence on tourist satisfaction.

Finally, satisfaction plays a critical role in predicting and understanding an individual's responses after a consumption experience. In this respect, the relationship between satisfaction and consumer loyalty has been widely explored and confirmed (e.g. Miguel-Dávila et al., 2010; Nam et al., 2011; Pleshko \& Heiens, 2015; Wu et al., 2012). Two main dimensions contribute to loyalty, considered as a consumer response based on brand commitment (Bloemer \& DeRuyter, 1998): the intention to repurchase and the willingness to recommend the brand (Andreassen \& Lindestad, 1998). The first one can be defined as the likelihood that consumers will buy the product or service again (Szymanski \& Henard, 2001) while the second is not only an indicator of the 
user's intention to continue the relationship with a firm but also a credible source of information for potential users (Maxham III, 2001).

Our study uses this attitudinal approach to loyalty instead of a behavioral focus (i.e. loyalty as a repeated behavior over time) for two reasons. On the one hand, the desire of individuals to seek variety in their destination experiences (Jang \& Feng, 2007) justifies the exploration of future intentions instead of past behaviors. On the other hand, the behavioral approach cannot distinguish between true loyalty and spurious loyalty (Chen \& Gursoy, 2001). In tourism, several studies have empirically confirmed that the intention to revisit a destination and the willingness to recommend it to other people are positively affected by tourist satisfaction (Bigné, et al., 2001; Lee et al., 2011; Ozdemir et al., 2012; Prayag \& Ryan, 2012; San Martín et al., 2013; Song et al., 2013; Yoon \& Uysal, 2005). In accordance with this evidence, the last hypothesis of this study is established:

H7. Tourist satisfaction will have a direct and positive influence on loyalty toward the destination.

Next, Figure 1 summarizes the research hypotheses formulated in this study.

FIGURE 1 NEAR HERE

\subsection{Cultural distance and destination brand equity}

Once the theoretical model has been established, we consider it is worth investigating in an exploratory way the role of the cultural distance between tourists and destinations in the study of destination brand equity. Cultural distance measures the extent to which consumers' origin cultures are different from or similar to the culture of the host (Ahn \& 
McKercher, 2015). According to the study of MacKay and Fesenmaier (2000), the cultural background of individuals filters their perceptions of a tourist destination. In this regard, several previous works have empirically demonstrated that the cultural distance with the destination influences the tourists' destination choice (Bi \& Letho, 2017) and the perceived image that tourists have of the place (San Martín \& Rodríguez, 2008; Kastenholz, 2010; Huang, Chen \& Lin, 2013).

Cultural distance can interplay with travel motivations. Specifically, novelty seeking and escape are two important motivational drivers for international travel; people may travel because they want to experience something completely new and different (Lee \& Crompton, 1992). In this sense, cultural distance promises opportunities for novelty for travelers (Bi \& Letho, 2017). On the opposite, commonplace or familiar trips fulfill other social demands such as kinship or social interactions (Snepenger, 1987).

Additionally, tourists typically purchase and consume a whole range of services, which together make up the "holiday or vacation experience", and they tend to base their judgements on the quality of and satisfaction with a vacation experience on all components of this complex tourism system (Klauss, 2000). With regard to this, Klauss (2000) and Lee and Lee (2009) highlight that the cultural distance may influence the overall valuation of the place and the tourism experience. In this line, our study establishes that the different cultural distance with the destination that have national and international tourists would lead to different cognitive and emotional connections with the place. In consequence, the origin of tourists may influence the intensity of the chain of effects proposed in our theoretical model. Specifically, taking into account the cultural distance as a control variable, we establish the following research question to be explored in our empirical research: 
RQ. Is the cultural distance between tourists and destination a variable that influence the chain of effects among the dimensions of destination brand equity?

\section{Methodology}

Quantitative research was carried out to test the factorial structure proposed in the theoretical model and to confirm our hypotheses. Data was collected using a questionnaire that included: 1) the dimensions of brand equity for the destination, 2) satisfaction during the stay at the destination, and 3) the socio-demographic profile of respondents. Particularly, the variables of the model were all measured using multiattribute instruments through ten-point Likert scales (see Appendix). In addition, several recommendations made by Sekaran (1983) and Churchill (1991) about research conducted in different languages were taken into account in order to assure the validity of our questionnaire. More concretely, the questionnaire was initially translated from Spanish to English by the researchers. Subsequently, one expert who is a native English speaker checked both accuracy and meaning of the translated items. Finally, we did a back translation into Spanish in order to ensure that both versions of the questionnaire were equivalent (several minor amendments were included in this process).

The target population for quantitative research consisted of national and international tourists, above 18 years of age, who were visiting the region of Cantabria in the north of Spain. The samples were selected by using the methods of quotas and convenience. In a first stage, we used a quota sampling method; particularly, according to the statistics provided by the Spanish Institute of Tourism Studies and the Cantabrian Institute of Statistics in terms of gender and age of the target population, we build a profile of 
national and international tourists to be surveyed. In a second phase, we used a convenience method where the main tourist attractions and infrastructures of the region of Cantabria were selected to collect empirical data in an efficient way. In this sense, data were gathered through a personal survey that was conveniently administered at the International Airport of Santander and the international tourist attractions of Cabárceno Wildlife Park and Altamira Caves during the summer of 2013. Taking into account that non-responses may provide a bias in the estimation of results (Lynn, 1996), we adopted the following strategy to avoid this problem: the interviewers were informed that, if during the data collection a questionnaire included a non-response for any item measuring the variables of the model, they had to repeat the survey with another tourist with similar characteristics.

With the aim of ensuring an adequate sample size, we considered two types of criteria previously established in Structural Equation Modeling Research. In this sense, Nunally (1967) originally indicated that at least 10 observations per indicator are necessary in SEM estimation; several more recent studies have suggested that the ratio (r) of indicators to latent variables is a better option (Boomsma, 1982; Marsh and Bailey, 1991). In particular, Marsh et al. (1999) suggest a sample of at least 400 if $r=$ 2.0, at least 200 if $r=3.0$, and at least 100 if $r=4.0$. Taking into account that our model includes six latent variables and twenty-one indicators $(\mathrm{r}=3.5)$, the lower bound is 210 tourists if we consider the first criterion and a sample of between 100 to 200 tourists if we used the second one. Finally, 667 responses (251 international tourists and 416 national tourists) were obtained since a significant effort was made to obtain a more representative sample in overall terms. The stratification and the socio-demographic characteristics of respondents are indicated in Tables 1 and 2, respectively. Particularly, 
the dominant profile are tourists aged 25 to 44 years (in coherence with the distribution of the population under investigation), workers and with university studies.

TABLE 1 NEAR HERE

TABLE 2 NEAR HERE

\section{Results}

Considering that method bias negatively affects the item validities and reliabilities, as well as the covariations between latent constructs (MacKenzie and Podsakoff, 2012), we initially performed Harman's single-factor test in order to check for the presence of the so-called "common method variance - CMV" (Chang et al., 2010). The results of the exploratory factor analysis executed in IBM-SPSS software indicate that all the items measuring the variables load into more than one factor; in particular, six factors (almost $70.0 \%$ of explained variance) were obtained in the analyses of both samples of tourists. Therefore, since these items are not concentrated in any one general factor, CMV is not expected to influence the results from quantitative research.

Subsequently, a covariance based Structural Equations Model (CB-SEM) approach is used to test the model. The choice of this statistical analysis is justified on a number of grounds (Hair et al., 2011, 2012): first, CB-SEM is particularly suited for testing and confirming well-founded theoretical models, as is the case in this research; second, it allows one to conduct Confirmatory Factor Analysis, to test the psychometric properties of the measurement instruments (reliability, and convergent and discriminant validity) according to the two-stage procedure proposed by Anderson and Gerbing (1988); third, it allows one to analyze the fit between the theoretical model proposed and the data 
(goodness-of-fit indexes); fourth, CB-SEM can be used to develop multi-group analysis, thus allowing one to compare the results obtained for different samples, as is the case in this research (national tourists and international tourists).

Particularly, CB-SEM analyses were run using a robust maximum-likelihood estimation procedure using EQS 6.1 software, in order to avoid problems of nonnormality of the data. First, the measurement model was estimated with confirmatory factor analysis (CFA) to test the psychometric properties of the measurement scales (reliability and validity). Next, the structural model was estimated in order to contrast the research hypotheses. Lastly, the effect of cultural distance as a control variable is tested through a multi-group analysis (national tourists versus international tourists), in order to check if the relationships established in the research model are affected by the cultural distance between tourists and destination.

\subsection{Confirmatory Factor Analysis}

The results obtained in the Confirmatory Factor Analysis support the reliability and convergent validity of the measurement scales in both samples of tourists (see Tables 3 and 4). The fit criteria indicate the extent to which the factorial model fits the empirical data. In particular, there are three main classes of fit criteria: measures of absolute fit, measures of incremental fit, and measures of parsimonious fit (Hair et al., 2010). In this case, the statistics, given by EQS 6.1 software, are widely used in the SEM literature (Hair et al., 2010): Bentler-Bonett Non-Normed Fit Index (BBNNFI) and Root Mean Square Error of Approximation (RMSEA) are used for the measurement of overall model fit; Incremental Fit Index (IFI) and Comparative Fit Index (CFI) are employed as 
measures of incremental fit; and Normed $\chi^{2}$ is used for the measurement of the parsimony of the model. The results summarized in Tables 3 and 4 confirm that, for both samples of tourists, the BBNNFI, IFI, and CFI statistics exceed or are very close to the recommended minimum value of 0.9. Similarly, in both cases RMSEA is located within the maximum limit of 0.08 , and Normed $\chi^{2}$ takes a value clearly under the recommended value of 3.0 (Hair et al., 2010).

The reliability of the measurement scales is evaluated using Cronbach's alpha and composite reliability coefficients (Bagozzi \& Yi, 1988). In general, the values of these statistics are clearly above the required minimum of 0.7 (Hair et al., 2010), thus supporting the inner reliability of the constructs (Tables 3 and 4). Only in the case of the affective image scale for the sample of national tourists are the coefficient values slightly under the recommended levels. However, given the good values obtained in the sample of international tourists, we have decided to maintain the same scale of affective image for both samples of tourists in order to allow an exact comparison between the results obtained.

TABLE 3 NEAR HERE

TABLE 4 NEAR HERE

Finally, none of the confidence intervals for pairs of latent constructs include 1.0 (Anderson \& Gerbing, 1998), thus supporting the discriminant validity of the model in both samples (see Tables 5 and 6).

TABLE 5 NEAR HERE

TABLE 6 NEAR HERE 


\subsection{Hypothesis testing}

The model was estimated in both samples of tourists in order to test the research hypotheses. A first estimation of the structural model showed that some relationships proposed in the research model were not significant for each of the samples considered (i.e. the relationship between cognitive image and quality in the sample of national tourists (hypothesis H3), and the relationship between awareness and affective image in the sample of international tourists (hypothesis H2). Accordingly, and following the model development approach proposed by Hair et al. (2010), the original model was reformulated to exclude the non-significant relationships for each sample. The results obtained for the respective re-specified structural models are summarized in Figures 2 and 3. The empirical results indicate that the goodness-of-fit indexes obtained are within or very near to the recommended values, thus confirming that the model adequately fits the data in both samples. In particular, for both samples the BBNNFI, IFI, and CFI statistics exceed or are very close to the recommended minimum value of 0.9 , RMSEA is located within the maximum limit of 0.08 , and Normed $\chi^{2}$ takes a value clearly under the recommended value of 3.0 (Hair et al., 2010).

Regarding the research hypotheses, the relationship between quality and satisfaction (standardized coefficient $=0.61, \mathrm{p}$-value $<0.05$ for national tourists, and standardized coefficient $=0.63, \mathrm{p}$-value $<0.05$ for international tourists $)$, as well as the relationship between satisfaction and loyalty (standardized coefficient $=0.51$, p-value $<0.05$ for national tourists, and standardized coefficient $=0.64$, p-value $<0.05$ for international tourists), are positive and statistically significant in both samples, thus supporting hypotheses H6 and H7. Therefore, a strong link between "quality-satisfaction-loyalty" 
is empirically demonstrated in this research. In addition, concerning the drivers of perceived quality, it is found that the influence of affective image on quality is positive and significant in both samples (standardized coefficient $=0.93$, p-value $<0.05$ for national tourists, and standardized coefficient $=0.58$, p-value $<0.05$ for international tourists), which support hypothesis H4. However, as previously established, the effect of cognitive image on quality is significant only in the sample of international tourists (standardized coefficient $=0.32$, p-value $<0.05$ ), so hypothesis H3 is only partially confirmed. Next, the hypothesis H5 is supported since cognitive image positively influence on affective image in both samples (standardized coefficient $=0.62$, p-value $<$ 0.05 for national tourists, and standardized coefficient $=0.65, \mathrm{p}$-value $<0.05$ for international tourists). Finally, it is found that the relationship between awareness and cognitive image is positive in both samples (standardized coefficient $=0.32$, p-value $<$ 0.05 for national tourists, and standardized coefficient $=0.32$, $\mathrm{p}$-value $<0.05$ for international tourists), supporting hypothesis H1. However, as previously established, the effect of awareness on affective image is significant only in the sample of national tourists (standardized coefficient $=0.26$, p-value $<0.05$ ) so hypothesis $\mathrm{H} 2$ is only partially confirmed.

FIGURE 2 NEAR HERE

FIGURE 3 NEAR HERE 


\subsection{Multi-group analysis: National vs international tourists}

A multi-group model was applied to analyze if all the causal effects included in the theoretical model are statistically different or not depending on the cultural distance between tourists and destination. Specifically, the multi-group models allow analyzing the equality of the parameters considered in a structural model between different groups (Byrne, 1994; Bentler, 2006). Thus, the multi-group models allow evaluation of the structural parameters for each sub-group, as well as compare the obtained value for each causal relation using the LM Test. Such a statistic requires the causal model to include aset of restrictions to equal the structural parameters of all groups being analyzed. In particular, the differences among groups using the statistics $\chi 2$ with a degree of freedom are analyzed comparing the restricted and non-restricted models. The results of the multi-group analysis are summarized in Table 7.

\section{TABLE 7 NEAR HERE}

The goodness-of-fit indexes of the multi-group model are clearly within the recommended values, thus confirming the adequacy of the research model to the data for the two samples analyzed. Once the goodness of fit of the model was confirmed, we analyzed if the moderating effect of cultural distance between tourists and destination on the causal effects included in the theoretical model is statistically significant. Thus, the structural coefficients obtained for the two groups identified - national tourists vs international tourists- were compared. Likewise, the results of the LM Test were analyzed for all causal relationships by considering the equality restriction among the parameters applied to each group. 
The results from the Lagrange Multiplier test (LM test) show that the only significant difference between national and international tourists is related to the causal effect of tourist satisfaction on loyalty ( $\mathrm{p}$-value $<0.05$ ). Specifically, the satisfaction with the destination experience has a stronger influence on intention to revisit the destination and willingness to recommend it to other people for the group of international tourists. In contrast, the chain of effects that lead to their satisfaction with the destination is very similar for both groups.

\section{Conclusions}

On the basis of the theory of customer-based brand equity, we establish a model that include the causal interrelationships among the dimensions of destination brand equity (i.e. awareness, image, perceived quality and loyalty) and the role of tourist satisfaction within this chain of effects. Additionally, in the development of our research model, we consider that destination image is integrated not only by cognitive associations, but also by affective ones. Consequently, we examine the effects of both dimensions of destination image separately as well as the interrelation between them. Finally, it is very important to emphasize that the theoretical model is empirically tested in two samples, national and international tourists. This approach allows identifying possible differences in the interrelations between the dimensions of brand equity because of the different cultural distance with the tourist destination. 


\subsection{Theoretical implications}

Our findings can be discussed by comparing and contrasting some related works. First, in line with Keller (2001) and the evidence recently obtained in tourism research, our study confirms the existence of a chain of effects among the dimensions of destination brand equity. However, this chain of effects is narrower and longer that the ones found in previous studies. More concretely, in contrast to several previous papers which test the interrelationships among the proposed dimensions (Bigné et al., 213; Kladou et al., 2014; Pike et al., 2010), our study demonstrates that the causal relationships between destination awareness, image, perceived quality and loyalty is sequential, so that awareness has a direct effect on destination image, which, in turn, is the direct determinant of perceived quality. In consequence, a higher brand awareness attributed by tourists to the destination will give place to a better image, which will then lead to a higher perceived quality of the destination, and consequently to a higher loyalty.

Second, one of the most important dimensions of destination brand equity is image (Konecnik \& Gartner, 2007). With regard to this, and in contrast to previous works that have measured destination image as a single construct - i.e. social image and self-image (Bigné et al., 2013; Boo et al., 2009; Kladou et al., 2014; Pike et al., 2010; Pike \& Bianchi, 2013;) — we considered two types of associations or image in our model of destination brand equity: cognitive image (i.e. beliefs regarding the characteristics of the destination), and affective image (i.e. feelings toward the place). This approach let us delve further into the multidimensional nature of destination image and, consequently, provide more exact knowledge about the influence of this variable on the formation of destination brand equity. Thus, we find that both dimensions of destination image are 
interrelated (in particular, affective image is positively influenced by cognitive image), so it can be concluded that the affective and cognitive associations together contribute to the representation of the destination in tourists' mind. However, our empirical evidence shows that, in the formation of quality judgements during the destination experience, the affective image is a more powerful driver than the cognitive image. This finding may be because the tourist experience, in contrast to other consumption contexts, has a much higher emotional content for individuals, which leads to a greater role of the emotions or feelings in their subjective evaluations.

Third, other theoretical contribution of this research is related to the effect of tourist satisfaction within the chain of effects among the dimensions of destination brand equity. Thus, while satisfaction has been widely studied in the literature on marketing and tourism, the effect of this variable had been very scarcely analyzed in the field of brand equity in tourism (Bigné et al., 2013). In this sense, the evidence obtained supports that satisfaction influences on loyalty towards the destination. Thus, once tourists have visited the destination, satisfaction appears as a key variable for brand equity, acting as a strong driver of loyalty in terms of the intention to revisit the destination and the willingness to recommend it to other people.

Finally, it is necessary to emphasize that the theoretical model was tested by considering two different samples: national and international tourists. In particular, our results offer support for the relationships of "quality-satisfaction" and "satisfactionloyalty" in both samples. Consequently, a strong link between "quality-satisfactionloyalty" is evidenced regardless of the origin of tourists. However, in the comparison between the two types of tourists, the difference regarding the role of the cognitive and affective image in the formation of quality judgments is remarkable. For international 
tourists, the cognitive associations significantly have a higher influence on the perceived quality of the destination, but the affective ones have a lesser effect in the formation of this judgement (in comparison to national tourists). This finding may be due to the international tourists' reduced emotional connection with the destination, which would be a consequence of an increased cultural distance with the place in comparison to the national tourists. Therefore, an increased distance between the tourist's cultural values and the culture that defines the destination could provoke a diminished contribution of affective image to the perceived quality of the tourist destination.

\subsection{Managerial implications}

These findings have important implications for attracting and fostering the loyalty of tourists. In this sense, given that brand awareness seems to be the "the ticket to enter the market" (Pike, 2007) and the first stage in the formation of brand equity, destination marketing organizations should first focus their efforts on fostering their brand awareness. Particularly, if a tourist destination is little known in the target market, traditional campaigns and social communication conducted by the destination should stress the brand name to make it more recognizable and renowned. This strategy is especially relevant in promoting a destination in international markets where tourist destinations are usually less well known to individuals. According to our findings, international tourists will form in part their quality judgements based on their cognitive associations with the place, which are positively influenced by their awareness of the destination. 
Destination communication should also contribute to build a positive and consistent image (brand associations) based both on cognitive and affective issues. Cognitive image is usually based on the main resources and attractions of the destination that are demanded by target segments, and for which the destination has competitive advantages. For example, Cantabria, a small coastal region in the north of Spain with an Atlantic mild weather, would focus on natural resources, heritage and gastronomy, instead of the traditional "sun and beach" image predominating in Spain. According to our findings, affective associations would have a greater role in the sequence "qualitysatisfaction-loyalty" than cognitive ones, so destination-marketing organizations should also focus on creating and/or reinforcing the affective image of the place within its positioning strategy. In consequence, positioning should be largely based on an amalgam of feelings and emotions (for example, pleasure, fun, excitement or amazement) that the destination is able to evoke among tourists on the basis of its resources and capabilities, and also taking into account the motivations of their different types of visitors.

Given that perceived quality and tourist satisfaction are key determinants of loyalty towards a destination, it is also very important that destination-marketing organizations conduct proactive and long-term management of both variables. In this sense, a good starting point would be to make a continuous assessment of the perceived quality of the destination and tourist satisfaction, with periodical research to control that these variables are within the desired levels. Additionally, communication campaigns should make a destination attractive for tourist but without generating unreachable expectations, which are based on an unreal image of the destination. Thus, according to the performance expectations theory, high perceived quality will positively influence 
tourist satisfaction as far as it matches or exceeds expectations. Finally, given the importance of perceived quality and satisfaction as determinants of tourist loyalty, it is recommended to implement customer recovery mechanisms in case of low perceived quality and satisfaction. Thus, destination marketing organizations and tourism companies should build the appropriate channels (e.g. physical offices, telephone service or web pages) to facilitate tourists' complaints and to provide a quick response in order to alleviate or solve quality problems or other causes of tourist dissatisfaction.

Finally, destination managers can increase the value of loyal tourists if they explicitly encourage them to revisit the destination and to recommend it to other people. On the one hand, future revisits of satisfied tourists can be fostered with direct marketing campaigns, reminding them of their previous experiences and informing them of new attractions and experiences. In some cases, promotional incentives such as discount coupons or special attention can be used to encourage revisits. On the other hand, loyal tourists can be a great source of positive word-of-mouth as they are willing to recommend a destination to other people. While, in the past, this phenomenon was limited to friends and family, information and communication technologies now allow electronic word-of-mouth, which has a global impact. Thus, destination marketing organizations and tourism companies can take advantage of these technologies, encouraging loyal tourists to post opinions and ratings on recommendation websites (for example, TripAdvisor) and to upload contents on social networks (for example, Facebook) and specialized platforms (for example, YouTube or Instagram). This effect can be amplified if destination marketing organizations and firms have their own profiles and sites on recommendation websites and social networks and use them to share and promote the electronic word-of-mouth from loyal tourists. 


\subsection{Limitations and further research}

Despite the rigorous methodology used in the design and development of the empirical research, this study has several limitations. The fact that this research focuses on a small region in the north of Spain could limit the generalization of the results. Therefore, it would be very interesting to test the model in other destinations with different degrees of brand awareness, cognitive and affective images and perceived quality. Nevertheless, Spain should be a relevant benchmark for the understanding of the relationship among the dimensions of destination brand equity as it is one of the major tourist destinations in the world.

Additionally, it would be interesting to continue studying the dimensionality of the cognitive and affective images of a destination, trying to isolate specific image dimensions applicable to any place but that could have a different effect depending on the type of tourist destination. For example, natural resources or heritage could be dimensions of cognitive image present in any destination but that would have a different impact on perceived quality or satisfaction for city tourism and mountain tourism. Similarly, the affective perception that a destination is quiet versus exciting could have a positive or negative effect on tourist satisfaction depending on travel motivations.

\section{References}

Aaker D.A. (1996). Building Strong Brands. New York: Free Press.

Aaker D.A, \& Joachimsthaler, E. (2000). The brand relationship spectrum: Key to the brand architecture challenge. California Management Review, 42(4), 8-23. 
Ahmed Z, Johnson J, Ling C, Fang T, \&Hui, A. (2010). Country-of -origin and brand effects on consumers' evaluations of cruise lines. International Marketing Review, 19(3), 279-302.

Ahn, M. \& McKercher, B. (2015).The effect of cultural distance on tourism: A study of international visitors to Hong Kong. Asia Pacific Journal of Tourism Research, 20(1), 94-113.

Alba J., \& Hutchinson, J.W. (1987). Dimensions of consumer expertise. Journal of Consumer Research, 13, 411-454.

Anderson, J.R. (1983). The Architecture of Cognition. Cambridge: Harvard University Press.

Anderson, J.C. \& Gerbing, D.W. (1988). Structural Equation Modelling in Practice: A Review and Recommended Two-Step Approach. Psychological Bulletin, 103(3), 411-423.

Andreassen, T.W, \& Lindestad, B. (1998). Customer loyalty and complex services. The impact of corporate image on quality, customer satisfaction and loyalty for customers with varying degrees of service expertise. International Journal of Service Industry Management, 9(1), 7-23.

Ashworth, G., \& Kavaratzis, M. (2007). Beyond the logo: Brand management for cities. Journal of Brand Management, 16(8), 520-531.

Bagozzi, R.P. (1982). A field investigation of causal relations among cognitions, affect, intentions, and behavior. Journal of Marketing Research, 19, 562-584.

Bailey, R., \& Ball, S. (2006). An exploration of the meanings of hotel brand equity. Service Industries Journal, 26(1), 15-38. 
Baker, D., \& Crompton, J. (2000). Quality, satisfaction and behavioral intentions. Annals of Tourism Research, 27(3), 785-804.

Balabanis, G., Mueller, R., \& Melewar, T.C. (2002). The human values’ lenses of country of origin images. International Marketing Review, 19(6), 582-610.

Baloglu, S. (2001). Image variations of Turkey by familiarity index: Informational and experiential dimensions. Tourism Management, 22, 127-133.

Baloglu, S, \& McCleary, K. (1999). A model of destination image formation. Annals of Tourism Research, 26(4), 868-897.

Barnes, S., Mattsson, J., \& Sørensen, F. (2014). Destination brand experience and visitor behavior: Testing a scale in the tourism context. Annals of Tourism Research, 48, 121-139.

Beerli, A., \& Martín, J.D. (2004). Factors influencing destination image. Annals of Tourism Research, 31, 657-681.

Bentler, P.M. (2006). EQS 6.1. Structural Equations Software Manual. Encino, CA: Multivariate Software, Inc.

Bi, J. \& Lehto, X. (2017). Impact of cultural distance on international destination on international destinations choices: the case of Chinese, outbound travellers. International Journal of Tourism Research. Available online.

Bigné, E., Sánchez, I., \& Sánchez, J. (2001). Tourism image, evaluation variables and after purchase behaviour: Inter- relationship. Tourism Management, 22(6), 607-616.

Bigné E., Sánchez, I., \& Sanz, S. (2005). Relationships among residents' image, evaluation of the stay and post-purchase behavior. Journal of Vacation Marketing, 11(4), 291-302. 
Bigné, E., Andreu, L., \& Zanfardini, M. (2013). El Valor de la Responsabilidad Social Corporativa en la Equidad de Marca de Destinos Turísticos. Madrid: Editorial Ramón Areces.

Bloemer, J., \& De Ruyter, K. (1998). On the relationship between store image, store satisfaction and store loyalty. European Journal of Marketing, 32(5-6), 499-513.

Bloemer, J., De Ruyter, J., \& Peeters, P. (1998). Investigating drivers of bank loyalty: The complex relationship between image, service quality and satisfaction. International Journal of Bank Marketing, 16(7), 276-286.

Boo, S., Busser, J., \& Baloglu, S. (2009). A model of customer-based brand equity and its application to multiple destinations. Tourism Management, 30, 219-231.

Boomsma, A. (1982). Robustness of LISREL against small sample sizes in factor analysis models. In K.G. Jöreskog and H. Wold (eds.), Systems under Indirect Observations, Causality, Structure, Prediction (Part 1, pp. 149-173), Amsterdam: North Holland.

Caldwell, N., \& Freire, J. (2004). The differences between branding a country, a region and a city: Applying the brand box model. Journal of Brand Management, 12(1), 5061.

Chen, C., \& Chen, F. (2010). Experience quality, perceived value, satisfaction and behavioral intentions for heritage tourists. Tourism Management, 31(1), 29-35.

Chen, C-S., \& Myagmarsuren, O. (2010). Exploring relationships between Mongolian destination brand equity, satisfaction and destination loyalty. Tourism Economics, 16(4), 981-994.

Chen, C., \& Tsai, D. (2007). How destination image and evaluative factors affect behavioral intentions?. Tourism Management, 28, 1115-1122. 
Chen, J.S, \& Gursoy, D. (2001). An investigation of tourists' destination loyalty and preferences. International Journal of Contemporary Hospitality Management, 13(2), $79-85$.

Churchill, G. A. (1991). Marketing research: Methodological focus. Hynsdale, IL: Dyrden Press.

Cordell, V.V. (1997). Consumer knowledge measures as predictors in product evaluation. Psychology and Marketing, 14(3), 241-260.

Cronin, J.J., Brady, M.K, \& Hult, G.T.M. (2000). Assessing the effects of quality, value, and customer satisfaction on consumer behavioral intentions in service environments. Journal of Retailing, 76(2), 193-218.

Dioko, S., \& So, I. (2012). Branding destinations versus branding hotels in a gaming destination. Examining the nature and significance of co-branding effects in the case study of Macao. International Journal of Hospitality Management, 31, 554-563.

Dooley, G., \& Bowie, D. (2005). Place brand architecture: Strategic management of the brand portfolio. Place Branding, 1(4), 402-419.

Fakeye, P.C, \& Crompton, J.L. (1991). Image differences between prospective, firsttime and repeat visitors to the Lower Rio Grande Valley. Journal of Travel Research, 30(2), 10-16.

Feldwick, P. (1996). Do we really need brand equity?. The Journal of Brand Management, 4(1), 9-28.

Fishbein, M., \& Ajzen, I. (1975). Belief, attitude, intention and behavior: An introduction to theory and research. Reading, MA: Addison-Wesley.

Fuchs, M., Chekalina, T., \& Lexhagen, M. (2012). Destination brand equity modeling and measurement. A summer tourism case from Sweden. In R.H. Tsiotsou and R.E. 
Goldsmith (Eds.) Strategic Marketing in Tourism Services (pp. 95-115). Wagon Lane Bingley: Emerald Group Publishing Limited.

Ghafari, M., Ranjbarian, B. \& Fathi, S. (2017). Developing a brand equity model for tourism destination, International Journal of Business Innovation and Research, 12, (4), 484-507

Gardner, B. B., \& Levy, S. J. (1955). The product and the brand. Harvard Business Review, March-April, 33-39.

Gartner, W., \& Koneckic, M. (2010). Tourism destination brand equity dimensions: Renewal versus repeat market. Journal of Travel research, 50(5), 471-481.

Gertner, D. (2011). Unfolding and configuring two decades of research and publications on place marketing and place branding. Place Branding and Public Diplomacy, 7(2), 91-106.

Gilmore, F. (2002). A country - Can it be repositioned? The success story of Spain. Journal of Brand Management, 9(4/5), 281-293.

Gounaris, S., Dimitriadis, S., \& Stathakopoulos, V. (2010). An examination of the effects of service quality and satisfaction on customers' behavioral intentions in eshopping. Journal of Services Marketing, 24(2), 142-156.

Hair, J.F., Anderson, R.E., Tatham, R.L., \& Black, W.C. (2010). Multivariate Data Analysis. 7th ed. New Jersey: Prentice Hall.

Han, C.M. (1989). Country image: Halo or summary construct?. Journal of Marketing Research, 26(2), 222-229.

Han, H., \& Hwang, J. (2016). Investigating healthcare hotel travelers' overall image formation: Impact of cognition, affect, and conation. Tourism and Hospitality Research, Available online. 
Hanna, S., \& Rowley, J. (2007). An analysis of terminology use in place branding. Place Branding and Public Diplomacy, 4, 61-75.

Hankinson, G. (2005). Destination brand images: A business tourism perspective. The Journal of Services Marketing, 19(1), 24-32.

Harish, R. (2010). Brand architecture in tourism branding: The way forward for India. Journal of Indian Business Research, 2(3), 153-165.

Hsu, C., Oh, H., \& Assaf, G. (2012). A customer based equity model for upscale hotels. Journal of Travel Research, 51(1), 81-93.

Huang, W-J., Chen, C-C., \& Lin, Y-H. (2013). Cultural proximity and intention to visit: Destination image of Taiwan as perceived by Mainland Chinese visitors. Journal of Destination Marketing \& Management, 2, 176-184.

Im, H., Kim, S., Ellio, S., \& Han, H. (2012). Conceptualizing destination brand equity dimensions from a customer-based equity perspective. Journal of Travel and Tourism Marketing, 29(4), 385-403.

Jang, S., \& Feng, R. (2007). Temporal destination revisit intention: The effects of novelty seeking and satisfaction. Tourism Management, 28(2), 580-590.

Javalgi, R.G., Cutler, B., \& Winans, B. (2001). At your service! Does country of origin research apply to services. The Journal of Services Marketing, 15(6/7), 565-582.

Jin, N., Lee, S., \& Lee, H. (2015). The effect of experience quality on perceived value, satisfaction, image and behavioral intention of water park patrons: New versus repeat visitors. International Journal of Tourism Research, 17(1), 82-95.

Kapferer, J.N. (2000). Strategic Brand Management. 2nd edition, London: Kogan Page. 
Kaplan, M., Yurt, O., Guneri, B., \& Kurtulus, K. (2010). Branding places: Applying brand personality concept to cities. European Journal of Marketing, 44(9/10), 12861304.

Kastenholz, E. (2010). Cultural proximity as a determinant of destination image. Journal of Vacation Marketing, 16(4), 313-322.

Keller, K.L. (1993). Conceptualizing, measuring, and managing customer-based brand equity. Journal of Marketing, 57(1), 1-22.

Keller, K.L. (2003). Strategic Brand Management: Building, Measuring, and Managing Brand Equity. 2nd ed. Upper Saddle River, NJ: Prentice Hall.

Kim, H., \& Richardson, S.L. (2003). Motion picture impacts on destination images. Annals of Tourism Research, 30(1), 216-237.

Kim, H., Holland, S., \& Han, S. (2013). A structural model for examining how destination image, perceived value, and service quality affect destination loyalty: A case study of Orlando. International Journal of Tourism Research, 15(4), 313-328.

Kladou, S., Giannopoulos, A. \& Mavragani, E. (2015). Destination brand equity research from 2001 to 2012. Tourism Analysis, 20(2), pp. 189-200.

Klaus, W. (2000). Tourists' perceptions towards and satisfaction with service quality in the cross-cultural service encounter: implications for hospitality and tourism management. Managing Service Quality, 10 (6), pp. 397-409.

Weiermair, Klaus . Managing Service Quality ; Bedford Vol. 10, Iss. 6, (2000): 397-409. Konecnik, M. (2006). Croatian-based brand equity for Slovenia as a tourism destination. Economic and Business Review for Central and South - Eastern Europe, 8(1), 83108. 
Konecnik, M., \& Gartner, W. (2007). Customer-based brand equity for a destination. Annals of Tourism Research, 34(2), 400-421.

Kotler, P., \& Gertner, D. (2002). Country as brand, product, and beyond: A place marketing and brand management perspective. Journal of Brand Management, $9(4 / 5), 249-261$.

Lee, T. H., \& Crompton, J. (1992). Measuring novelty seeking in tourism. Annals of Tourism Research, 19(4), 732-751.

Lee, G., \&Lee, C.K. (2009).Cross-cultural comparison of the image of Guam perceived by Korean and Japanese leisure travelers: Importance-performance analysis. Tourism Management, 30(6), 922-931.

Lee, S., Jeon, S., \& Kim, D. (2011). The impact of tour quality and tourist satisfaction on tourist loyalty: The case of Chinese tourists in Korea. Tourism Management, $32(5), 1115-1124$.

Lim, Y., \& Weaver, P.A. (2014). Customer-based brand equity for a destination: The effect of destination image on preference for products associated with a destination brand. International Journal of Tourism Research, 16(3), 223-231.

Lin, C-H., Morais, D.B., Kerstetter, D.L., \& Hou, J-S. (2016). Examining the role of cognitive and affective image in predicting choice across natural, developed, and theme-park destinations. Journal of Travel Research. Available online.

Liu, C. \& Fang, Y. (2016). Conceptualizing, validating, and managing brand equity for tourist satisfaction. Journal of Hospitality \& Tourism Research. Available online.

Lynn, P. 1996. Weighting for non-response, In Survey and Statistical Computing (pp. 205-214), Ed. R. Banks. London: Association for Survey Computing. 
MacKenzie, S.B., \& Podsakoff, P.M. (2012). Common method bias in marketing: Causes, mechanisms, and procedural remedies. Journal of Retailing, 88(4), 542-555.

Marsh, H. W., \& Bailey, M. (1991). Confirmatory factor analyses of multitraitmultimethod data: A comparison of alternative models. Applied Psychological Measurement, 15 (1), 47-70.

Maxham III, J.G. (2001). Service recovery's influence on consumer satisfaction, positive word-of-mouth, and purchase intentions. Journal of Business Research, $54(1), 11-24$.

Miguel-Dávila, J.A., Cabeza-García, L., Valdunciel, L., \& Flórez, M. (2010). Operations in banking: The service quality and effects on satisfaction and loyalty. Service Industries Journal, 30(13), 2163-2182.

Nam, J., Ekinci, J., \& Whyatt, G. (2011). Brand equity, brand loyalty and consumer satisfaction. Annals of Tourism Research, 38(3), 1009-1030.

Nunnally, J.C. (1967). Psychometric Theory. New York: McGraw-Hill.

Olsen, S.O. (2002). Comparative evaluation and the relationship between quality, satisfaction, and repurchase loyalty. Journal of the Academy of Marketing Science, $30(2), 240-249$.

Ozdemir, B., Aksu, A., Ehtiyar, R., Çizel, R.B., \& Içigen, E.T. (2012). Relationships among tourist profile, satisfaction and destination loyalty: Examining empirical evidences in Antalya Region of Turkey. Journal of Hospitality Marketing and Management, 21(5), 506-540.

Papadimitriou, D., Kaplanidou, K., \& Apostolopoulou, A. (2016). Destination image components and word-of-mouth intentions in urban tourism: A multigroup approach. Journal of Hospitality \& Tourism Research. Available online. 
Petrick, J.F. (2004). The roles of quality, value, and satisfaction in predicting cruise passengers' behavioral intentions. Journal of Travel Research, 42(4), 397-407.

Pike, S.D. (2007). Customer-based brand equity for destinations: Practical DMO performance measures. Journal of Travel and Tourism Marketing, 22(1), 51-61.

Pike, S.D. (2009). Destination brand positions of a competitive set of near-home destinations. Tourism Management, 30(6), 857-866.

Pike, S.D. (2010). Destination branding case study: tracking brand equity for an emerging destination between 2003 and 2007. Journal of Hospitality \& Tourism Research, 34(1), 124-139.

Pike, S., Bianchi, C., \& Kerr, G. (2010). Customer-based brand equity for Australia as a long-haul tourism destination in an emerging market. International Marketing Review, 27(4), 434-449.

Pike, S., \& Ryan, C. (2004). Destination positioning analysis through a comparison of cognitive, affective, and conative perceptions. Journal of Travel Research, 42(4), 333-342.

Pike, S. \& Bianchi, C. (2016). Destination brand equity for Australia: testing a model of CBBE in short-haul and long-haul Markets, Journal of Hospitality \& Tourism Research, 40 (1), 114-134

Pleshko, L.P., \& Heiens, R.A. (2015). Customer satisfaction and loyalty in the Kuwaiti retail services market: Why are satisfied buyers not always loyal buyers?. International Review of Retail, Distribution and Consumer Research, 25(1), 55-71.

Prayag, G. (2012). Paradise for who? Segmenting visitors' satisfaction with cognitive image and predicting behavioural loyalty. International Journal of Tourism Research, 14(1), 1-15. 
Prayag, G., \& Ryan, C. (2012). Antecedents of tourists' loyalty to Mauritius: The role and influence of destination image, place attachment, personal involvement, and satisfaction. Journal of Travel Research, 51(3), 342-356.

Rodríguez, I., \& San Martín, H. (2008). Tourist satisfaction. A cognitive-affective model. Annals of Tourism Research, 35(2), 551-573.

San Martín, H., Collado, J., \& Rodríguez I. (2013). An exploration of the effects of past experience and tourist involvement on destination loyalty formation. Current Issues in Tourism, 16(4), 327-342.

San Martín, H., \& Rodríguez, I. (2008). Exploring the cognitive-affective nature of destination image and the role of psychological factors in its formation. Tourism Management, 29, 263-277.

Sekaran, U. (1983). Methodological and theoretical issues and advancements in crosscultural research. Journal of International Business Studies, 14, 61-73.

Smith, W.W., Li, X., Pan, B., Witte, M., \& Doherty, T. (2015). Tracking destination image across the trip experience with smartphone technology. Tourism Management, 48, 113-122.

Song, Z., Su, X., \& Li, L. (2013). The indirect effects of destination image on destination loyalty intention through tourist satisfaction and perceived value: The bootstrap approach. Journal of Travel and Tourism Marketing, 30(4), 386-409.

Snepenger, D. J. (1987). Segmenting the vacation market by novelty seeking role. Journal of Travel Research, 26(2), 8-14.

Srivastava, K., \& Sharma, N.K. (2013). Service quality, corporate brand image, and switching behavior: The mediating role of customer satisfaction and repurchase intention. Services Marketing Quarterly, 34(4), 274-291. 
Syssner, J. (2009). Place branding from a multi-level perspective. Place Branding and Public Diplomacy, 6(1), 36-48.

Szymanski, D.M., \& Henard, D.H. (2001). Customer satisfaction: A meta-analysis of the empirical evidence. Journal of the Academy of Marketing Science, 29(1), 16-35.

Van Raaij, W.F., Van Veldhoven, G.M., \& Wärneryd, K.E. (2013). Handbook of Economic Psychology. Springer Science \& Business Media.

Walmsley, D., \& Young, M. (1998). Evaluative images and tourism: The use of personal constructs to describe the structure of destination Images. Journal of Travel Research, 36, 65-69.

Wu, X., Zhou, H., \& Wu, D. (2012). Commitment, satisfaction, and customer loyalty: A theoretical explanation of the satisfaction trap. Service Industries Journal, 32(11), $1759-1774$.

Yacout, O.M., \& Hefni, L.I. (2015). Use of Hofstede's cultural dimensions, demographics, and information sources as antecedents to cognitive and affective destination image for Egypt. Journal of Vacation Marketing, 21(1), 37-52.

Yang, Y., Liu, X., \& Li, J. (2015). How customer experience affects the customer-based brand equity for tourism destinations. Journal of Travel and Tourism Marketing, $32(1), 97-113$.

Yasin, N., Noor, N., \& Mohamad, O. (2007). Does image of country-of-origin matter to brand equity?. Journal of Product and Brand Management, 16(1), 38-48.

Yoon, Y., \& Uysal, M. (2005). An examination of the effects of motivation and satisfaction on destination loyalty: A structural model. Tourism Management, 26(1), $45-56$. 
Zabkar, V., Brencic, M., \& Dmitrovic, T. (2010). Modelling perceived quality, visitor satisfaction and behavioural intentions at the destination level. Tourism Management, $31,537-546$.

Zenker, S. (2009). Who's your target? The creative class as a target group for place branding. Journal of Place Management and Development, 2(1), 23-32.

Zhang, L., \& Zhao, S.X. (2009). City branding and the Olympic effect: A case study of Beijing. Cities, 26, 245-254. 


\section{Appendix: Measurement scales ${ }^{\text {a }}$}

Awareness of the destination (adapted from Boo et al., 2009; Pike et al., 2010)

The region of Cantabria is a clearly recognizable tourist destination

The region of Cantabria is a famous tourist destination

The region of Cantabria is a well-known tourist destination

Cognitive image of the destination (adapted from San Martín and Rodríguez, 2008)

Natural environment (landscape, beaches, natural parks...)

Cultural heritage (monuments, museums, folklore...)

Tourist infrastructure (accommodation, restaurants, shopping...)

Leisure and recreation activities (sport, adventure...)

Local cuisine

Hospitality

Affective image of the destination (adapted from San Martín and Rodríguez, 2008)

The region of Cantabria is a pleasant destination

The region of Cantabria is a fun destination

The region of Cantabria is an amazing destination

Perceived quality of the destination (adapted from Boo et al., 2009)

Tourism resources in the region of Cantabria are attractive

Tourism products and services in the region of Cantabria are excellent

Offer quality in the region of Cantabria is high

Loyalty toward the destination (adapted from Konecnik and Gartner, 2007; Boo et al., 2009;

Pike et al., 2010)

I will try to come back to the region of Cantabria

I will encourage my family and friends to visit the region of Cantabria

I would recommend the region of Cantabria if someone asked me

Satisfaction with the destination (adapted from Rodríguez and San Martín, 2008)

I have enjoyed my stay in the region of Cantabria

My choice of the region of Cantabria has been right

I'm satisfied with my experience in the region of Cantabria

${ }^{a}$ All the variables were measured by using a ten-point Likert scale $(1=$ strongly disagree; $10=$ strongly agree). 


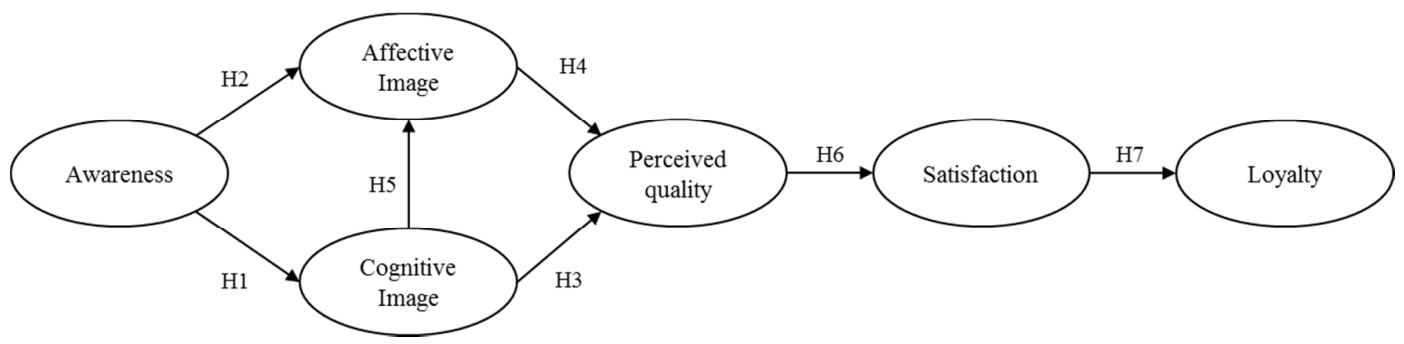

Figure 1. Theoretical model 


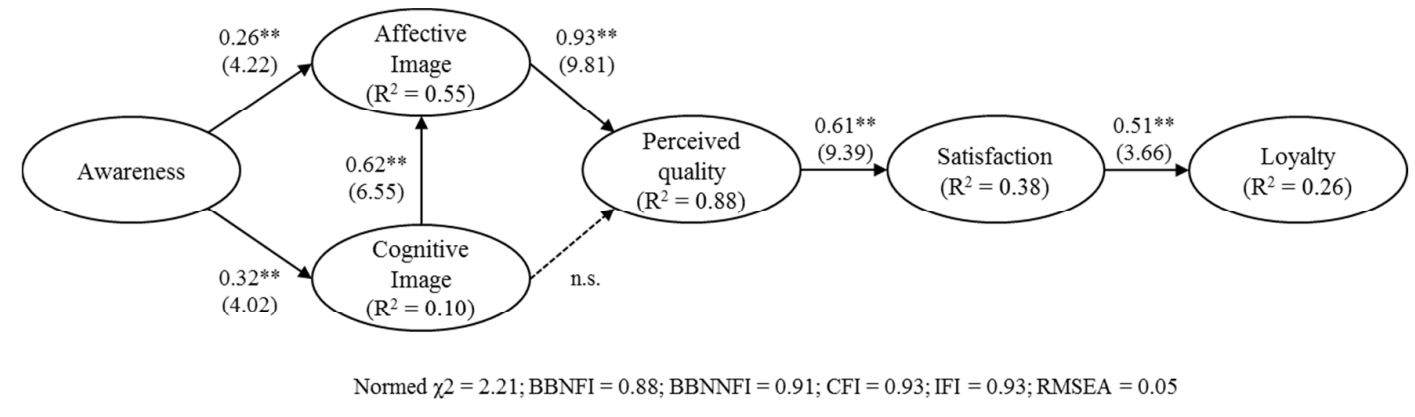

Figure 2. Estimation of the model (national tourists) 


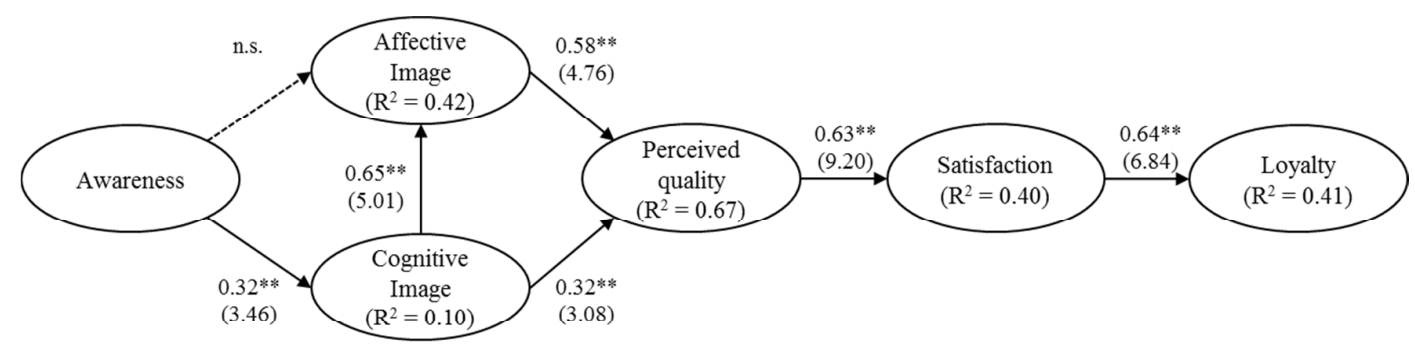

Normed $\chi 2=1.94 ; \mathrm{BBNFI}=0.84 ; \mathrm{BBNNFI}=0.90 ; \mathrm{CFI}=0.91 ; \mathrm{IFI}=0.91 ; \mathrm{RMSEA}=0.06$

Figure 3. Estimation of the model (international tourists) 
Table 1. Socio-demographic stratification (population vs sample)

\begin{tabular}{|c|c|c|c|c|}
\hline & \multicolumn{2}{|c|}{$\begin{array}{l}\text { National tourists } \\
\qquad(n=416)\end{array}$} & \multicolumn{2}{|c|}{$\begin{array}{l}\text { International tourists } \\
\qquad(\mathrm{n}=\mathbf{2 5 1})^{\mathrm{a}}\end{array}$} \\
\hline & $\begin{array}{c}\text { Population } \\
(\%)\end{array}$ & $\begin{array}{c}\text { Sample } \\
(\%)\end{array}$ & $\begin{array}{c}\text { Population } \\
(\%)\end{array}$ & $\begin{array}{c}\text { Sample } \\
(\%)\end{array}$ \\
\hline Gender & & & & \\
\hline Male & 51.2 & 51.5 & 52.0 & 52.6 \\
\hline Female & 48.8 & 48.5 & 48.0 & 47.4 \\
\hline Age & & & & \\
\hline 18-24 years & 7.6 & 8.6 & 12.6 & 13.8 \\
\hline $25-44$ years & 34.9 & 36.6 & 44.2 & 44.7 \\
\hline $45-64$ years & 46.4 & 44.9 & 33.7 & 33.2 \\
\hline 65 or more years & 11.1 & 9.9 & 9.5 & 8.3 \\
\hline
\end{tabular}

${ }^{a}$ Although international tourists only represent around the $10.0 \%$ of the tourists visiting Cantabria every year, this group is overrepresented in the sample to obtain a more reliable estimation of the research model. 
Table 2. Socio-demographic profile of respondents

\begin{tabular}{|l|c|c|c|}
\hline \multicolumn{2}{|c|}{ National tourists } & \multicolumn{2}{c|}{ International tourists } \\
\hline Education level & $\%$ & Education level & $\%$ \\
\hline Less than primary & 3.8 & Less than primary & 3.6 \\
\hline Primary & 13.7 & Primary & 6.0 \\
\hline Secondary & 32.4 & Secondary & 21.5 \\
\hline University & 50.1 & University & 68.9 \\
\hline Occupation & & Occupation & \\
\hline Worker & 60.8 & Worker & 65.1 \\
\hline Student & 12.1 & Student & 17.5 \\
\hline Housewife & 9.9 & Housewife & 5.2 \\
\hline Unemployed/retired & 17.2 & Unemployed/retired & 12.2 \\
\hline Region of origin & $\%$ & Country of origin & $\%$ \\
\hline Madrid & 24.8 & United Kingdom & 23.3 \\
\hline Castilla y León & 14.2 & Germany & 15.0 \\
\hline Cataluña & 10.9 & Ireland & 14.6 \\
\hline Andalucía & 8.7 & Netherlands & 9.1 \\
\hline C. Valenciana & 8.7 & France & 6.7 \\
\hline País Vasco & 7.8 & Italy & 5.1 \\
\hline Castilla - La Mancha & 5.4 & Belgium & 3.6 \\
\hline Aragón & 4.7 & United States & 2.8 \\
\hline Other regions & 14.8 & Other countries & 19.8 \\
\hline
\end{tabular}


Table 3. Confirmatory Factor Analysis (national tourists)

\begin{tabular}{|c|c|c|c|c|c|c|}
\hline Factor & Variable & $\begin{array}{c}\text { Standard } \\
\text { Coefficient }\end{array}$ & $\begin{array}{c}\text { Explained } \\
\text { variance }\left(\mathbf{R}^{2}\right)\end{array}$ & $\begin{array}{c}\text { Cronbach's } \\
\alpha\end{array}$ & $\begin{array}{l}\text { Composite } \\
\text { Reliability }\end{array}$ & $\begin{array}{l}\text { Goodness of fit } \\
\text { indices }\end{array}$ \\
\hline \multirow{3}{*}{ Loyalty } & LOY1 & 0.480 & 0.231 & \multirow{3}{*}{0.789} & \multirow{3}{*}{0.836} & \\
\hline & LOY2 & 0.896 & 0.803 & & & \\
\hline & LOY3 & 0.952 & 0.915 & & & \\
\hline \multirow{3}{*}{ Satisfaction } & SAT1 & 0.847 & 0.717 & \multirow{3}{*}{0.908} & \multirow{3}{*}{0.907} & \\
\hline & \begin{tabular}{|l|} 
SAT2 \\
\end{tabular} & 0.867 & 0.752 & & & \\
\hline & SAT3 & 0.909 & 0.826 & & & \\
\hline \multirow{3}{*}{ Perceived quality } & QUA1 & 0.753 & 0.568 & \multirow{3}{*}{0.822} & \multirow{3}{*}{0.824} & \\
\hline & QUA2 & 0.781 & 0.609 & & & \\
\hline & QUA3 & 0.808 & 0.652 & & & Normed $\chi^{2}=1.85$ \\
\hline \multirow{3}{*}{ Affective Image } & AFFA1 & 0.736 & 0.541 & \multirow{3}{*}{0.647} & \multirow{3}{*}{0.673} & $\mathrm{BBNNFI}=0.94$ \\
\hline & AFFA2 & 0.594 & 0.352 & & & $\mathrm{IFI}=0.95$ \\
\hline & AFFA3 & 0.578 & 0.334 & & & $\mathrm{CFI}=0.95$ \\
\hline \multirow{6}{*}{ Cognitive Image } & COGA1 & 0.501 & 0.251 & \multirow{6}{*}{0.738} & \multirow{6}{*}{0.747} & $\mathrm{RMSEA}=0.05$ \\
\hline & COGA2 & 0.625 & 0.391 & & & \\
\hline & COGA3 & 0.606 & 0.367 & & & \\
\hline & COGA4 & 0.586 & 0.344 & & & \\
\hline & COGA5 & 0.566 & 0.321 & & & \\
\hline & COGA6 & 0.559 & 0.313 & & & \\
\hline \multirow{3}{*}{ Awareness } & AWA1 & 0.736 & 0.542 & \multirow{3}{*}{0.869} & \multirow{3}{*}{0.873} & \\
\hline & AWA2 & 0.864 & 0.746 & & & \\
\hline & AWA3 & 0.897 & 0.804 & & & \\
\hline
\end{tabular}


Table 4. Confirmatory Factor Analysis (international tourists)

\begin{tabular}{|c|c|c|c|c|c|c|}
\hline Factor & Variable & $\begin{array}{c}\text { Standard } \\
\text { coefficient }\end{array}$ & $\begin{array}{c}\text { Explained } \\
\text { variance }\left(\mathbf{R}^{2}\right)\end{array}$ & $\begin{array}{c}\text { Cronbach's } \\
\alpha\end{array}$ & $\begin{array}{l}\text { Composite } \\
\text { Reliability }\end{array}$ & $\begin{array}{c}\text { Goodness of fit } \\
\text { indices }\end{array}$ \\
\hline \multirow{3}{*}{ Loyalty } & LOY1 & 0.640 & 0.409 & \multirow{3}{*}{0.834} & \multirow{3}{*}{0.871} & \\
\hline & LOY2 & 0.917 & 0.841 & & & \\
\hline & LOY3 & 0.918 & 0.843 & & & \\
\hline \multirow{3}{*}{ Satisfaction } & SAT1 & 0.877 & 0.769 & \multirow{3}{*}{0.893} & \multirow{3}{*}{0.896} & \\
\hline & SAT2 & 0.911 & 0.830 & & & \\
\hline & SAT3 & 0.793 & 0.628 & & & \\
\hline \multirow{3}{*}{ Perceived quality } & QUA1 & 0.732 & 0.536 & \multirow{3}{*}{0.829} & \multirow{3}{*}{0.832} & \\
\hline & QUA2 & 0.805 & 0.648 & & & \\
\hline & QUA3 & 0.827 & 0.684 & & & Normed $\chi^{2}=1.66$ \\
\hline \multirow{3}{*}{ Affective Image } & AFFA1 & 0.770 & 0.593 & \multirow{3}{*}{0.784} & \multirow{3}{*}{0.790} & $\mathrm{BBNNFI}=0.93$ \\
\hline & AFFA2 & 0.706 & 0.499 & & & $\mathrm{IFI}=0.94$ \\
\hline & AFFA3 & 0.762 & 0.580 & & & $\mathrm{CFI}=0.94$ \\
\hline \multirow{6}{*}{ Cognitive Image } & COGA1 & 0.436 & 0.190 & \multirow{6}{*}{0.703} & \multirow{6}{*}{0.716} & RMSEA $=0.05$ \\
\hline & COGA 2 & 0.459 & 0.211 & & & \\
\hline & COGA 3 & 0.705 & 0.497 & & & \\
\hline & COGA 4 & 0.643 & 0.414 & & & \\
\hline & COGA 5 & 0.557 & 0.310 & & & \\
\hline & COGA 6 & 0.444 & 0.197 & & & \\
\hline \multirow{3}{*}{ Awareness } & AWA1 & 0.832 & 0.691 & \multirow{3}{*}{0.910} & \multirow{3}{*}{0.912} & \\
\hline & AWA2 & 0.894 & 0.799 & & & \\
\hline & AWA3 & 0.913 & 0.834 & & & \\
\hline
\end{tabular}


Table 5. Confidence interval for the correlations between pairs of latent variables (National tourists)

\begin{tabular}{|c|c|c|c|c|c|}
\hline & Loyalty & Satisfaction & Perceived quality & Affective Image & Cognitive Image \\
\hline \multirow{2}{*}{ Satisfaction } & $0.504^{\mathrm{a}}$ & & & & \\
\hline & $(0.352 ; 0.656)^{\mathrm{b}}$ & & & & \\
\hline \multirow{2}{*}{ Perceived quality } & 0.403 & 0.499 & & & \\
\cline { 2 - 6 } & $(0.267 ; 0.539)$ & $(0.399 ; 0.599)$ & & & \\
\hline \multirow{2}{*}{ Affective Image } & 0.546 & 0.778 & 0.838 & & \\
\cline { 2 - 7 } & $(0.422 ; 0.670)$ & $(0.708 ; 0.848)$ & $(0.754 ; 0.922)$ & & \\
\hline \multirow{2}{*}{ Cognitive Image } & 0.371 & 0.565 & 0.622 & 0.673 & \\
\cline { 2 - 6 } & $(0.207 ; 0.535)$ & $(0.457 ; 0.673)$ & $(0.510 ; 0.734)$ & $(0.569 ; 0.777)$ & \\
\hline \multirow{2}{*}{ Awareness } & 0.265 & 0.204 & 0.440 & 0.424 & 0.317 \\
\cline { 2 - 6 } & $(0.135 ; 0.395)$ & $(0.096 ; 0.312)$ & $(0.332 ; 0.548)$ & $(0.304 ; 0.544)$ & $(0.195 ; 0.439)$ \\
\hline
\end{tabular}

a Correlation among variables

${ }^{\mathrm{b}}$ Confidence interval for high correlations 
Table 6. Confidence interval for the correlations between pairs of latent variables (International tourists)

\begin{tabular}{|c|c|c|c|c|c|}
\hline & Loyalty & Satisfaction & Perceived quality & Affective Image & Cognitive Image \\
\hline \multirow{2}{*}{ Satisfaction } & $0.617^{\mathrm{a}}$ & & & & \\
\hline & $(0.519 ; 0.715)^{\mathrm{b}}$ & & & & \\
\hline \multirow{2}{*}{ Perceived quality } & 0,551 & 0.534 & & & \\
\hline & $(0.419 ; 0.683)$ & $(0.420 ; 0.648)$ & & & \\
\hline \multirow{2}{*}{ Affective Image } & 0.608 & 0,711 & 0.724 & & \\
\hline & $(0.486 ; 0.565)$ & $(0, .621 ; 0.801)$ & $(0.608 ; 0.840)$ & & \\
\hline \multirow{2}{*}{ Cognitive Image } & 0,424 & 0,538 & 0.637 & 0.635 & \\
\hline & $(0.278 ; 0.570)$ & $(0.404 ; 0.672)$ & $(0.509 ; 0.765)$ & $(0.509 ; 0.761)$ & \\
\hline \multirow{2}{*}{ Awareness } & 0,087 & 0,088 & 0.368 & 0,243 & 0.274 \\
\cline { 2 - 6 } & $(-0.049 ; 0.223)$ & $(-0.058 ; 0.234)$ & $(0.236 ; 0.500)$ & $(0.099 ; 0.387)$ & $(0.108 ; 0.440)$ \\
\hline
\end{tabular}

a Correlation among variables

${ }^{\mathrm{b}}$ Confidence interval for high correlations 
Table 7. Multi group analysis: National vs international tourists

\begin{tabular}{|c|c|c|c|c|}
\hline & $\begin{array}{c}\text { Stand. Coef } \\
\text { National tourists }\end{array}$ & $\begin{array}{c}\text { Stand. Coef } \\
\text { International tourists }\end{array}$ & $\begin{array}{l}\text { LM Test } \\
\text { (p-value) }\end{array}$ & Goodness of fit \\
\hline H1: Awareness $\rightarrow$ Cognitive Image & 0.32 & 0.29 & 0.25 & \multirow{7}{*}{$\begin{array}{c}\chi^{2} \text { Normed }=2.11 \\
\text { BBNNFI }=0.91 \\
\text { IFI }=0.92 \\
\text { CFI }=0.92 \\
\text { RMSEA }=0.04\end{array}$} \\
\hline H2: Awareness $\rightarrow$ Affective Image ${ }^{\text {a }}$ & 0.27 & 0.10 & - & \\
\hline H3: Cognitive Image $\rightarrow$ Perceived Quality $^{b}$ & 0.06 & 0.30 & - & \\
\hline H4: Affective Image $\rightarrow$ Perceived Quality & 0.89 & 0.60 & 0.09 & \\
\hline H5: Cognitive Image $\rightarrow$ Affective Image & 0.60 & 0.60 & 0.33 & \\
\hline H6: Perceived Quality $\rightarrow$ Satisfaction & 0.61 & 0.63 & 0.29 & \\
\hline H7: Satisfaction $\rightarrow$ Loyalty & 0.51 & 0.64 & $0.01 * *$ & \\
\hline
\end{tabular}

${ }^{a}$ Causal relationship non-significant in the individual analysis for international tourists.

${ }^{\mathrm{b}}$ Causal relationship non-significant in the individual analysis for national tourists.

**Differences between standardized coefficients for each sample are significant at $\mathrm{p}$-value $<0.05$. 
We would like to thank Reviewer for his/her comments. Next, we detail the modifications included in the new version of the paper, together with our comments for the reviewer:

\section{Introduction:}

It should conclude with the objective, explaining and justifying it clearly.

We have detailed the objective of our paper in the last paragraph of the Introduction: "In brief, the overall objective of our paper is to generate new knowledge about destination brand equity by adopting a new approach, which is focused on: 1) the interrelationships among brand equity dimensions, 2) the tourist satisfaction as a key behavioral variable in loyalty formation, and 3) the geographical and cultural distance between tourist and destination as a potential variable influencing the chain of effects in the model. With this in mind, the present paper is organized as follows; first, (...)".

The development of a multi-group analysis should be highlighted in the introduction and the abstract.

In addition, we have mentioned the multi-group analysis as follows:

Abstract: "(...). The model was tested in two samples, national and international tourists visiting a destination in Spain, in order to also explore the role of the geographical and cultural distance between tourist and destination. Our results from a multi-group analysis indicate: (...)".

Introduction - fifth paragraph: "(...). Since the different geographical and cultural origins of tourists may lead to different perceptions and mental structures regarding the destination concerned, a multi-group analysis was conducted in order to identify if the chain of effects included in our model of destination brand equity is significantly different or not between the two groups of tourists".

\section{Literature review:}

More current researches should be included.

Attending to the reviewer's suggestion, we have included the following new references in our paper:

Ahn, M. \& McKercher, B. (2015).The effect of cultural distance on tourism: A study of international visitors to Hong Kong. Asia Pacific Journal of Tourism Research, 20(1), 94-113. Cited on page 11.

Bi, J. \& Lehto, X. (2017). Impact of cultural distance on international destination on international destinations choices: the case of Chinese, outbound travellers. International Journal of Tourism Research. Available online. Cited on page 12.

Ghafari, M., Ranjbarian, B. \& Fathi, S. (2017). Developing a brand equity model for tourism destination, International Journal of Business Innovation and Research, 12, (4), 484-507. Cited on page 3 and page 7.

Liu, C. \& Fang, Y. (2016). Conceptualizing, validating, and managing brand equity for tourist satisfaction. Journal of Hospitality \& Tourism Research. Available online. Cited on page 7. 
Pike, S. \& Bianchi, C. (2016). Destination brand Equity for Australia: testing a model of CBBE in short-haul and long-haul Markets, Journal of Hospitality \& Tourism Research, 40 (1), 114-134. Cited on page 2.

The section 2.2 should be presented clearer, as it is a little confusing.

We have introduced the following modifications in order to improve the presentation of section 2.2:

a) The sections 2.2 and 2.3 analyze the chain of effects among the dimensions of brand equity. The section 2.2 includes five hypotheses related to the relationship between awareness, image and quality, so it has been renamed as "Chain of effects among the dimensions of brand equity: awareness, image and quality". Furthermore, we have enumerated each block of hypotheses so that the sequence is clearer:

"First, we analyze the awareness-image relationship. According to different approaches (...)".

"Second, previous research on consumer behavior has widely recognized that perceptions of quality are influenced by the perceived image of a product or service (...)"

"Finally, and as previously established in the introduction, it is necessary to examine not only the influence of these two dimensions of destination image on other constructs, but also the possible link between them (...)".

b) The section 2.3 analyses the role of satisfaction in this process. We have moved the last paragraph of the section 2.2 (in the previous version of the paper) to this section and we have added more explanatory information.

"Customer-based brand equity implies a direct relationship between perceived quality and consumer loyalty. However, according to consumer behavior literature (Gounaris et al., 2010; Srivastava \& Sharma, 2013), if individuals have direct experience with a product (e.g. destination), their future behavior will also be affected by their satisfaction with the consumption experience. Thus, we include this variable in our theoretical model, and we examine the role of satisfaction considering its antecedents and its influence on loyalty towards the destination".

Literature review cannot include the own author's reflection, as all comments must be supported by previous studies. For instance, the authors say: "However, we consider that it would be very interesting to separately examine how destination awareness influences the two dimensions of destination image, i.e. cognitive and affective image" in page 7.

We have modified the section slightly and we have deleted this sentence in the new version of our paper (Page 7). 
Brand awareness influences the formation of these associations, so it is to be expected that a greater awareness of a destination will enhance the perception of its brand image (Bigné et al., 2013; Pike et al., 2010; Liu \& Fang, 2016; Ghafari et al. 2017).

In tourism research, destination image (i.e. brand image) is defined as the set of impressions, beliefs, ideas, expectations and feelings accumulated towards a tourist destination over time (Kim \& Richardson, 2003). This approach to destination image, which includes both cognitive and affective associations, has been supported by recent studies about destination image (e.g. Han \& Hwang, 2016; Lim \& Weaver, 2014; Lin et al., 2016; Papadimitriou et al., 2016; Smith et al., 2015; Yacout \& Hefny, 2015). In this sense, since a tourist destination is capable of evoking different emotions, such as pleasure or excitement, among visitors (Walmsley \& Young, 1998), destination image would be represented not only by the beliefs or knowledge an individual has of the attributes of the destination (Pike and Ryan, 2004) but also by his/her feelings toward the place (Chen \& Uysal, 2002; Kim \& Richardson, 2003).

Accordingly, this study adopts a cognitive-affective approach of destination image when establishing the interrelationships between this construct and other variables such as awareness and perceived quality. Therefore, based on the brand equity theory, this research establishes that a greater awareness of the destination will enhance not only the cognitive associations linked to the place by tourists, but also the affective ones. Consequently, the following hypotheses are established:

The section 2.4 should be improved including some more previous studies.

We have tried to improve the section 2.4, adding new references and explanations:

"Once the theoretical model has been established, we consider it is worth investigating in an exploratory way the role of the cultural distance between tourists and destinations in the study of destination brand equity. Cultural distance measures the extent to which consumers' origin cultures are different from or similar to the culture of the host (Ahn \& McKercher, 2015). According to the study of MacKay and Fesenmaier (2000), the cultural background of individuals filters their perceptions of a tourist destination. In this regard, several previous works have empirically demonstrated that the cultural distance with the destination influences the tourists' destination choice (Bi \& Letho, 2017) and the perceived image that tourists have of the place (San Martín \& Rodríguez, 2008; Kastenholz, 2010; Huang, Chen \& Lin, 2013).

Cultural distance can interplay with travel motivations. Specifically, novelty seeking and escape are two important motivational drivers for international travel; people may travel because they want to experience something completely new and different (Lee \& Crompton, 1992). In this sense, cultural distance promises opportunities for novelty for travelers (Bi \& Letho, 2017). On the opposite, commonplace or familiar trips fulfill other social demands such as kinship or social interactions (Snepenger, 1987)"

Additionally, tourists typically purchase and consume a whole range of services, which together make up the "holiday or vacation experience", and they tend to base their judgements on the quality of and satisfaction with a vacation experience on all components of this complex tourism system (Klauss, 2000). With regard to this, Klauss (2000) and Lee and Lee (2009) highlight that the cultural distance may influence the 
overall valuation of the place and the tourism experience. In this line, our study establishes that the different cultural distance with the destination that have national and international tourists would lead to different cognitive and emotional connections with the place.

3. Methodology:

More information about the sampling procedure should be added. When was the sample collected?

According to the reviewer's comment, we have provided more information about the sampling procedures and data collection (3. Methodology - second paragraph):

"(...). The samples were selected by using the methods of quotas and convenience. In a first stage, we used a quota sampling method; particularly, according to the statistics provided by the Spanish Institute of Tourism Studies and the Cantabrian Institute of Statistics in terms of gender and age of the target population, we build a profile of national and international tourists to be surveyed. In a second phase, we used a convenience method where the main tourist attractions and infrastructures of the region of Cantabria were selected to collect empirical data in an efficient way. In this sense, data were gathered through a personal survey that was conveniently administered at the International Airport of Santander and the international tourist attractions of Cabárceno Wildlife Park and Altamira Caves during the summer of 2013".

\section{Results and conclusions:}

More explanation relative to the current analysis should be considered in the sections $\mathbf{4 . 2}$ and 4.3., explaining in more detail the results obtained.

According to the reviewer's suggestion we have extended the explanation of the results in sections 4.2. and 4.3. In particular, first paragraph in section 4.2 has been rewritten as follows:

The model was estimated in both samples of tourists in order to test the research hypotheses. A first estimation of the structural model showed that some relationships proposed in the research model were not significant for each of the samples considered (i.e. the relationship between cognitive image and quality in the sample of national tourists (hypothesis $\mathrm{H} 3$ ), and the relationship between awareness and affective image in the sample of international tourists (hypothesis $\mathrm{H} 2$ ). Accordingly, and following the model development approach proposed by Hair et al. (2010), the original model was reformulated to exclude the non-significant relationships for each sample. The results obtained for the respective re-specified structural models are summarized in Figures 2 and 3. The empirical results indicate that the goodness-of-fit indexes obtained are within or very near to the recommended values, thus confirming that the model adequately fits the data in both samples. In particular, for both samples the BBNNFI, $I F I$, and CFI statistics exceed or are very close to the recommended minimum value of 0.9, RMSEA is located within the maximum limit of 0.08 , and Normed $\chi^{2}$ takes a value clearly under the recommended value of 3.0 (Hair et al., 2010). 
Additionally, the values of the standardized coefficients and p-values for each relationships in both samples have been included in second paragraph of section 4.2.

Finally, in section 4.3. we now provide a more detailed explanation of the multi-group analysis:

A multi-group model was applied to analyze if all the causal effects included in the theoretical model are statistically different or not depending on the cultural distance between tourists and destination. Specifically, the multi-group models allow analyzing the equality of the parameters considered in a structural model between different groups (Byrne, 1994; Bentler, 2006). Thus, the multi-group models allow evaluation of the structural parameters for each sub-group, as well as compare the obtained value for each causal relation using the LM Test. Such a statistic requires the causal model to include aset of restrictions to equal the structural parameters of all groups being analyzed. In particular, the differences among groups using the statistics $\chi 2$ with a degree of freedom are analyzed comparing the restricted and non-restricted models. The results of the multi-group analysis are summarized in Table 7.

The goodness-of-fit indexes of the multi-group model are clearly within the recommended values, thus confirming the adequacy of the research model to the data for the two samples analyzed. Once the goodness of fit of the model was confirmed, we analyzed if the moderating effect of cultural distance between tourists and destination on the causal effects included in the theoretical model is statistically significant. Thus, the structural coefficients obtained for the two groups identified - national tourists vs international tourists- were compared. Likewise, the results of the LM Test were analyzed for all causal relationships by considering the equality restriction among the parameters applied to each group. 